Original article

https://www.journal-imab-bg.org

\title{
INVESTIGATION OF ANTIMICROBIAL EFFECT OF PHOTODYNAMIC THERAPY WITH FOTOSAN IN LABORATORY CONDITIONS
}

\author{
Vasil Kalchinov ${ }^{1}$, Raina Gergova ${ }^{2}$ \\ 1) Department of Conservative Dentistry, Faculty of Dental Medicine, Medical \\ University, Sofia, Bulgaria \\ 2) Medical Microbiology, Faculty of Medicine, Medical University, Sofia, Bul- \\ garia.
}

\section{SUMMARY}

Purpose: The present study aims to evaluate antimicrobial effect of photosensitizer Fotosan against microorganisms from endodontic flora.

Material and methods: Staphtlococcusaureus ATCC29213 (MSSA), S.aureus ATCC43300 (MRSA), Enterococcus faecalis ATCC 29212, Pseudomonas aeruginosa ATCC 27853, Escherichia coli ATCC 25922 were used as control strains and test bacteria. Several clinical isolates like E. faecalis, Klebsiella pneumoniae, Enterobacter cloaceae, Serratia marcescens, Morganela morganii were used supplementary. Suspensions with concentration 0.5 at MacFarland's scale and Muller-Hinton agar were used according to criteria of EUCAST 2019. The used Fotosan was with the lowest viscosity. Plates with diameter of 100 millimeters were used in the study. The three filter paper disks were put on inoculated with testing microbial strain agar surface. The disks were consecutively soaked with $0.5 \mathrm{ml}$ of Fotosan. LED lamp with $\lambda=630 \mathrm{~nm}$ was a source of light. Output power was $200 \mathrm{~mW}$. The power density was $700 \mathrm{~mW} / \mathrm{cm}^{2}$. The three disks have been consecutively illuminated, the first for 20 seconds, the second for $40 \mathrm{sec}-$ onds and the third for 60 seconds. The plates were cultivated for 24 hours at aerobic conditions at $36^{\circ} \mathrm{C}$ after that.

Results: The zones of inhibition of bacterial growth have varied from 8 to $10 \mathrm{~mm}$ for Gram-positive bacteria and 6 to $8 \mathrm{~mm}$ for Gram-negative bacteria.

Conclusion: The presence research has confirmed that photodynamic therapy with Fotosan is an effective method for liquidation of microorganisms, especially with more expression antimicrobial effect against Gram-positive bacteria, which participate more often in endodontic microbial pathology.

Keywords: endodontic microbiology, photodynamic therapy

\section{INTRODUCTION}

Photodynamic therapy (PDT) is a modern method using for elimination of cancer cells and microorganisms $[1,2]$. It presents a great success in dental medicine for treating of oral pathological microorganisms, in conserva- tive dentistry for liquidation of bacteria in deep cavities. It is used in endodontic like an additional treatment method for disinfection of root canals, in periodontology against microbes in periodontal pockets [3]. Specific chemical compounds called photosensitizers (PS) are used for carrying out a PDT. Basic physical characteristics of PS are: First, they have intensive absorbing of light in the visual or far red spectral zone. Photosensitizes possess high quantum production of generated singlet oxygen. They must possess a high affinity to pathological target cells. The aim is optimum accumulation and retention of PS for conducting of photo-oxidation with quick elimination from the tissues after that $[4,5,6]$. Photosensitizer activates available oxygen in tissues under the action of light with a certain wavelength. There are two types of reactions that pass. First type photodynamic reaction passes in the present of $\mathrm{H}_{2} \mathrm{O}$, and a heavy quantity of active $\mathrm{OH}$ radicals are formed. These free radicals can react with biomolecules in a bacterial cell, or they can react until it is formed $\mathrm{H}_{2} \mathrm{O}_{2}$, which is highly cytotoxic [5, 6 ]. Second type of photodynamic reaction. Photosensitizer reacts with molecule oxygen, and it is formed singlet oxygen which reacts with surround structures like RNA, DNA, cell wall and proteins. Singlet oxygen has a short life, and this provides local action. That way, PDT leads to the destruction of microbial cells [7]. Numerous natural and synthetic compounds can be used for photosensitizers. Thoroughly three-cycle dyes have been used for effect on $\mathrm{MO}$ at the beginning like: acridine orange, methylene blue, toluidine blue and etc. They have limited capability like PS, but they are used in dental medicine [4]. Oral candidiasis treated with toluidine blue [8]. Phenothiazine chloride is used for the treatment of chronic periodontitis. It is demonstrated in laboratory researches that PDT reduces bacteria significantly in infected root canals. LAZERs and LED lamps are used as sources of light $[9,10]$.

\section{AIM OF STUDY}

The aim of the present study was to evaluate the antimicrobial effect of photosensitizer Fotosan (based on toluidine blue) against facultative anaerobic Gram-positive and Gram-negative bacteria by the help of the disk-diffusion method (DDM). 


\section{MATERIAL AND METHODS}

Following bacterial strains were included in this investigation: Staphylococcus aureus ATCC29213 (MSSA), Staphylococcus aureus ATCC43300 (MRSA), Enterococcus faecalis ATCC 29212, Pseudomonas aeruginosa ATCC 27853, Escherichia coli ATCC 25922. These were used for controls of DDM according to recommendations of the European Committee on Antimicrobial Susceptibility Testing. Clinical Breakpoint Tables - bacteria; Version 9.0 2019; (EUCAST). Several clinical isolates like E. faecalis, Klebsiella pneumoniae, Enterobacter cloaceae, Serratia marcescens, Morganela morganii were used in addition. The whole method was executed according to instructions in this document. Suspension with concentration 0.5 at MacFarland's scale from 24 hours pure bacterial culture of testing microbial strain was used for the aim of the study. The concentration of bacterial suspension was determined by using of a nephelometer. Muller-Hinton agar was used nutritious medium. It was used Fotosan (with the lowest viscosity) that it is used in endodontic. The nutritious medium was spread in plates with diameter 100 millimeters. The depth of nutritious medium was 4 millimeters. The three filter paper disks were put on inoculated with testing microbial strain agar surface. The disks were consecutively soaked with $0.5 \mathrm{ml}$ of Fotosan. LED lamp with $\lambda=630 \mathrm{~nm}$ was a source of light (Fig. 1). Output power was $200 \mathrm{~mW}$. The power density was $700 \mathrm{~mW} / \mathrm{cm}^{2}$.

Fig. 1. LED lamp.

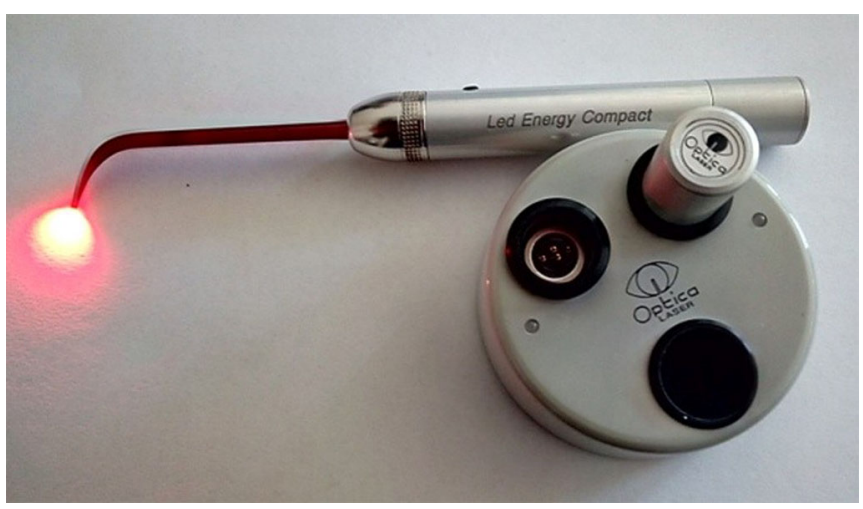

The three disks have been consecutively illuminated, the first for 20 seconds, the second for 40 seconds and the third for 60 seconds. The plates were cultivated for 24 hours at aerobic conditions at $36^{\circ} \mathrm{C}$ after that.

\section{RESULTS}

The zones of bacterial growth inhibition were varied from 8 to $10 \mathrm{~mm}$. for Gram-positive bacteria (Fig. 2 and Fig. 3) and 6 to $8 \mathrm{~mm}$ for Gram-negative bacteria (Fig.4 and Fig. 5). The largest zones of inhibition of bacterial growth were detected at illumination with photosensitizer for 40 seconds.
Fig. 2. Inhibition of E. faecalis growth.

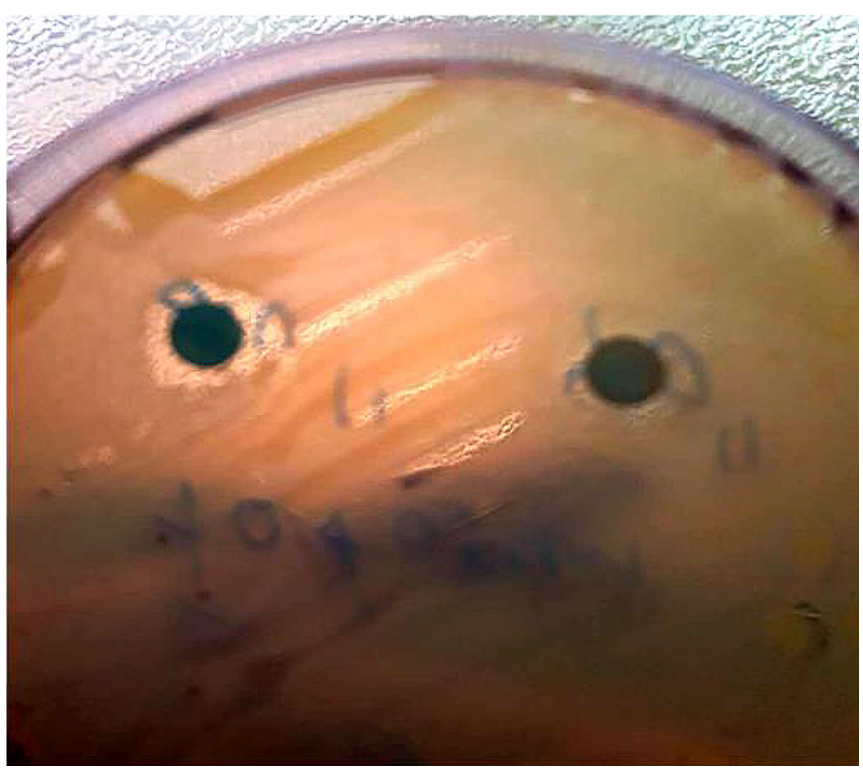

Fig. 3. Inhibition of $S$. aureus growth.

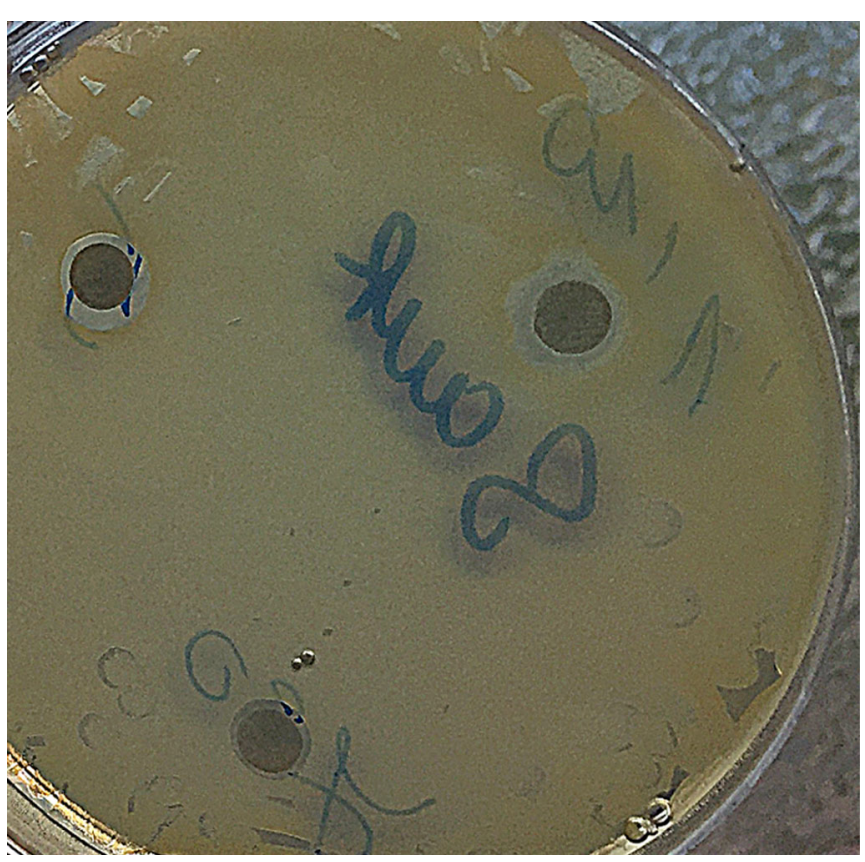


Fig. 4. Results of E. coli growth inhibition.

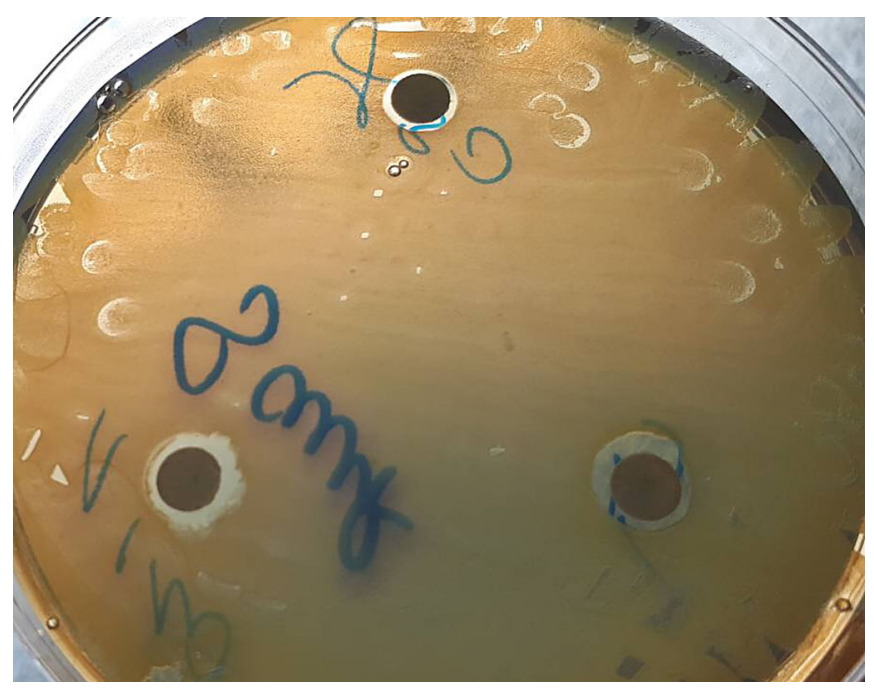

Fig. 5. Results of $P$. aeruginosa inhibition.

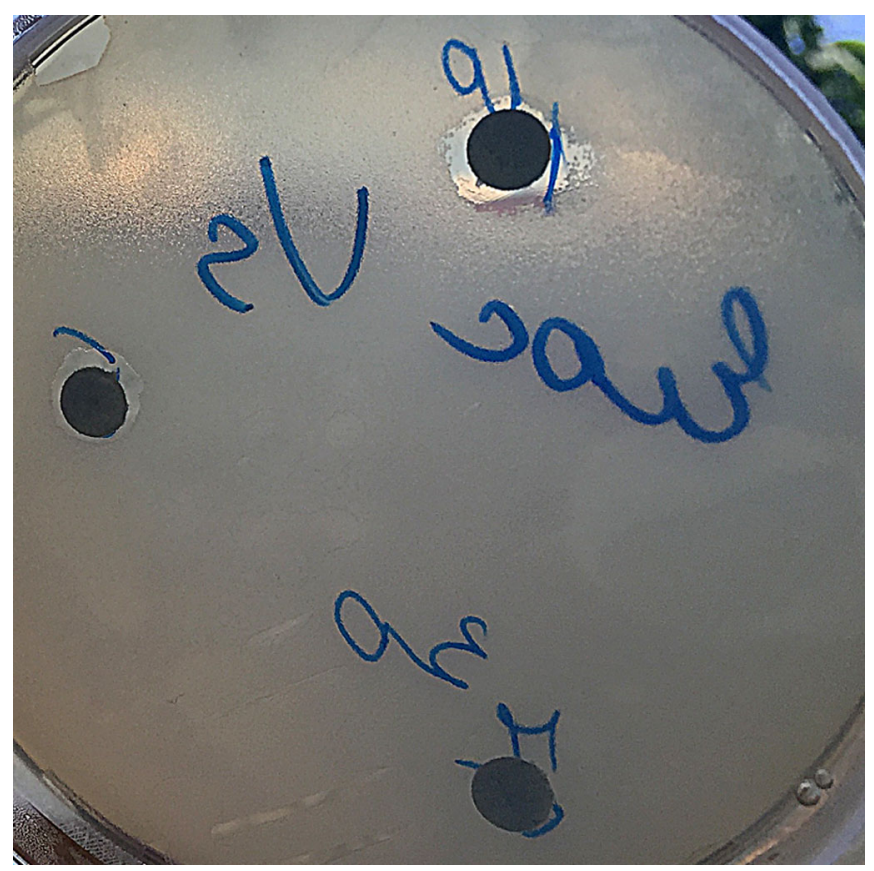

\section{DISCUSSION}

The DDM is one of the most often used methods for antimicrobial activity assessment $[11,12,13,14]$. Several factors that are relevant for diffusion capacity of materials in agar must be considered, such as the contact between experimental material and agar, molecular weight, size and shape of the antimicrobial agent, load and concentration of test material, agar gel viscosity, ionic concentration in relation to medium, plate-storage conditions and etc. [11, 12]. Furthermore, control and standardization of inoculation density, evaluation of results, selection of agar medium, selection of MO, depth of agar medium, incubation temperature of plates, and reading point of inhibition haloes are also restricting factors. These factors affect the dynamics and variability of diffusion test in an agar medium. Standardization of these factors allows us to exclude numerous variables existing in vivo
$[13,14]$. The disadvantage of DDM is that all these factors can be difficult put to standardization [11]. Other disadvantages of this method are relatively insensitive and semi-quantitative and do not distinguish between bacteriostatic or bactericidal properties of the material [12]. In addition, the results of DDT does not depend on only the toxicity of the material for the particular microorganism but are highly influenced by the diffusibility of the material across the medium. Therefore, only water-soluble agents can be tested. Materials that diffuse more easily will probably provide larger zones of inhibition of bacterial growth $[11,12]$.

The smaller inhibition zones can be explained with the smaller diffusion of Fotosan in agar medium, although chemical compound with the lowest viscosity was used in this investigation. Despite the fact that the results in this examination were unsatisfactory in relationship to antimicrobial quality of Fototsan, in another study with the same photosensitizer, its antimicrobial effect was quite powerful against E. faecalis and S. aureus, and it was quite weaker against $P$. aeruginosa [4]. This is evidence about its high efficacy in relation to PDT. Results in this study are in conformity with the other examination where it was detected the powerful antimicrobial effect of photosensitizer toluidine blue against E. faecalis [15]. Gergova et al. [16] have carried out FDT with Fotosan, and they were detected better disinfection of root canals infected with E. faecalis and disinfection was considerably weaker when canals were infected with $P$. aeruginosa. It was detected a powerful antimicrobial effect of FDT with toluidine blue against periodontal pathogens like $A$. acitnomycetemcomitans, Porphyromonas gingivalis, Prevotella intermedia $[17,18]$. Photodynamic therapy with $\mathrm{CO}_{2}$-laser or Nd: YAG laser and toluidine blue were effective against Streptococcus mutans, and it may be useful in the prevention of caries [19]. It is with first-rank importance chemical-mechanical preparation of root canals for the elimination of infection in them, regardless of the good effect of FDT with photosensitizers like methylene blue or toluidine blue [20].

It was performed extended zones of inhibition of bacterial growth in other our study with DDT [21]. Iodine/ Potassium iodide, Cupral, $\mathrm{Ca}(\mathrm{OH})_{2}$-high dispersion, Cresophene, Rockle were used in this examination. The biggest zones of inhibition of bacterial growth were detected at $\mathrm{I}_{2} / \mathrm{KI}$ and Cresophene from 22 to $13 \mathrm{~mm}$ when test bacterium was E. faecalis, and from 37 to $23.5 \mathrm{~mm}$ for test bacterium $S$. aureus. When the test bacterium was strict anaerobic such as Prvotella spp., Cupral and Cresophene had the most powerful antibacterial effect, zones of inhibition were from 36 to $32.5 \mathrm{~mm}$. The larger zones of inhibition of bacterial growth can be explained with efficient diffusion in the agar medium at some of the medicines in contrast to Fotosan. In the other study with modified DDT, it was achieved to a similar conclusion, when the sterile disks were substituted with preliminarily prepared and sterilized teeth roots. E. faecalis and $S$. aureus were used for test bacteria like the previous study [22]. The apex of the roots was immersed into agar me- 
dium. The same medicines like the previous examination, were introduced with application or iontophoresis. When the drugs were introduced with the application, there were not detected zones of inhibition of bacterial growth. It can be explained with the absence of diffusion of the medicine through root's foramen apical. Whereas the medicines Cupral, $\mathrm{Ca}(\mathrm{OH})_{2}$ and $\mathrm{I}_{2} / \mathrm{KI}$ were introduced with iontophoresis, there were detected big zones of inhibition of bacterial growth from 30 to $33.5 \mathrm{~mm}$ at test bacterium $E$. faecalis and from 20 to $25 \mathrm{~mm}$. at test bacterium $S$. aureus. Therefore a large quantity of the drugs have passed through foramen apiclale at iontophoresis. These results were confirmed and from another study when Cupral and $I_{2} / K$, I had powerful antimicrobial action against biofilms from E. faecalis and Pseudomonas aeruginosa [16]. Independently of poor results obtained in this study, numerous authors stated the high effectiveness of Fotosan (toluidine blue) like photosensitizer against many bacteria [15, 16, 17, 19$]$.

\section{CONCLUSION}

The present research was confirmed that photodynamic therapy with Fotosan is an effective method for in vitro liquidation of tested microbes. It has more expression antimicrobial effect against Gram-positive bacteria, which participate more often in endodontic microbial pathology.

\section{REFERENCES:}

1. Maeda H, Tsukigawa K, Fang J. A Retrospective 30 Years After Discovery of the Enhanced Permeability and Retention Effect of Solid Tumors: Next-Generation Chemotherapeutics and Photodynamic Therapy-Problems, Solutions, and Prospects. Microcirculation. 2016 Apr;23(3):173-82. [PubMed] [Crossref]

2. Plotino G, Grande NM, Mercade M. Photodynamic therapy in endodontics. Int Endod J. 2019 Jun;52(6):760774.[PubMed] [Crossref]

3. Moreira A, Novaes A, Grisi M, Taba M, Souza S, Palioto D, et al. Antimicrobial Photodynamic Therapy as an Adjunct to Non-Surgical Treatment of Aggressive Periodontitis: A SplitMouth Randomized Controlled Trial. J Periodontol. 2015 March;86(3):376386. [PubMed] [Crossref]

4. Georgieva Tz. [Possibilities of photo-activated disinfection and radiation of ND: YAG LASER for elimination of endodontic microflora.] [dissertation] Medical University of Sofia, (Bulgaria). 2015. 188 p. [in Bulgarian]

5. Ahmad MZ. Anti-microbial Photo Dynamic Therapy (aPDT) in Endodontics: A Literature Review. Int J Dental Scien Res. 2018 Feb;6(2):25-28. [Crossref]

6. Cieplik F, Deng D, Crielaard W, Buchalla W, Hellwig E, Al-Ahmad A, et al. Antimicrobial Photodynamic Therapy - What We Know and What We Don't. Crit Rev Microbiol. 2018 Sep;44(5):571-589. [PubMed] [Crossref]

7. Hu X, Huang YY, Wang Y, Wang $X$, Hamblin MR. Antimicrobial Photodynamic Therapy to Control Clinically
Relevant Biofilm Infections. Front Microb. 2018 Jun 27;9:1299. [PubMed] [Crossref]

8. Hosseini N, Yazdanpanah S, Saki M, Rezazadeh F, Ghapanchi J, Zomorodian K. Susceptibility of Candida albicans and Candida dubliniensis to Photodynamic Therapy Using Four Dyes as the Photosensitizer. $J$ Dent (Shiraz). 2016 Dec;17(4):354-360. [PubMed]

9. Ablon G. Phototherapy with Light Emitting Diodes: Treating a Broad Range of Medical and Aesthetic Conditions in Dermatology. J Clin Aesthet Dermatol. 2018 Feb;11(2):21-27. [PubMed]

10. Sorbellini E, Rucco M, Rinaldi F. Photodynamic and photobiological effects of light-emitting diode (LED) therapy in dermatological disease: an update. Lasers Med Science. 2018 Sep; 33(7):1431-1439. [PubMed] [Crossref]

11. Nalawade TM, Bhat KG, Sogi S. Antimicrobial Activity of Endodontic Medicaments and Vehicles using Agar Well Diffusion Method on Facultative and Obligate Anaerobes. Int J Clinic Ped Dent. 2016 Oct-Dec; 9(4): 335 341. [PubMed] [Crossref]

12. Omidi S, Hoshyari N, Mirzadeh AR, Hassanabadi ME, Ahajan M, Charati JY, et al. Comparison of Antibacterial Activity of Three Endodontic Sealers against Enterococcus faecalis. J Res Med Dent Sci. 2018 Feb;6(1): 413-417.

13. Poggio C, Trovati F, Ceci M, Colombo M, Pietrocola G. Antibacterial activity of different root canal sealers against Enterococcus faecalis. J Clin Exp Dent. 2017 Jun 1;9(6):e743-e748.

\section{[PubMed] [Crossref]}

14. Yadav P, Chaudhary S, Saxena RK, Talwar S, Yadav S. Evaluation of Antimicrobial and Antifungal efficacy of Chitosan as endodontic irrigant against Enterococcus Faecalis and Candida Albicans Biofilm formed on tooth substrate. J Clin Exp Dent. 2017 Mar; 9(3):e361-e367. [PubMed] [Crossref]

15. Rödig T, Endres S, Konietschke F, Zimmermann O, Sydow HG, Wiegand A. Effect of fiber insertion depth on antibacterial efficacy of photodynamic therapy against Enterococcus faecalis in root canals. Clin Oral Investig. 2017 Jun;21(5):1753-1759 [PubMed] [Crossref]

16. Gergova RT, Gueorgieva Tz, Dencheva-Garova M, Krasteva-Panova AZ, Kalchinov V, Mitov I, et al. Antimicrobial activity of different disinfection methods against biofilms in root canals. J Investig Clinic Dent. 2016 Aug;7(3):254-262 [PubMed] [Crossref]

17. Ghasemi M, Etemadia A, Nedaei M, Chiniforush N, Pourhajibagher M. Antimicrobial Efficacy of Photodynamic Therapy Using Two Different Light Sources on the Titanium-Adherent Biofilms of Aggregatibacter Actinomycetemcomitans: An in Vitro Study. Photodiagnosis Photodyn Ther. 2019 Jun;26(3):85-89. [PubMed] [Crossref]

18. Oruba Z, Labuz P, Macyk W, Chomyszyn-Gajewska M. Periopathogens differ in terms of the susceptibility to toluidine blue O-mediated photodynamic inactivation. Photodiagnosis Photodyn Ther. 2017 Dec; 20(12):28-34. [PubMed] [Crossref]

19. Yassaei S, Zandi H, Aghili H, 
Rafiei E, Mosayebi N. Evaluation of the effect of two types of laser on the growth of Streptococcus mutans. Laser Ther. 2018 Jun 30;27(2):119-123. [PubMed] [Crossref]

20. Afkhami F, Akbari S, Chiniforush N. Entrococcus faecalis Elimination in Root Canals Using Silver
Nanoparticles, Photodynamic Therapy, Diode Laser, or Laser-activated Nanoparticles: An In Vitro Study. J Endod. 2017 Feb;43(2):279-282. [PubMed] [Crossref]

21. Kalchinov V, Dimitrov $\mathrm{S}$, Belcheva M. In vitro study of bactericidal effect of antimicrobial agents used in modern endodontics. $J$ of IMAB. 2009; 15(2):79-83 [Crossref]

22. Dimitrov $\mathrm{S}$, Kalchinov V, Belcheva M. Investigation of the bactericidal effect by modified agar - diffusion method. Dent Medicine. 2011; 93(1):24-31.

Please cite this article as: Kalchinov V, Gergova R. Investigation of antimicrobial effect of photodynamic therapy with Fotosan in laboratory conditions. J of IMAB. 2020 Jul-Sep;26(3):3308-3312.

DOI: https://doi.org/10.5272/jimab.2020263.3308

Received: 15/08/2019; Published online: 09/09/2020

Address for correspondence:

Assist. Prof. Vasil Kalchinov, DMD, PhD; Department of Conservative dentistry, Faculty of Dental Medicine, Medical University of Sofia,

1, G. Sofijski str 1. 1431"Sofia, Bulgaria.

E-mail: vasko_kalchinov@mail.bg, 